To Gerard Greenway and in memory of Urs Jaeggi 


\section{Earth Hymn}

'Guardian and friend of the moon, O Earth, whom the comets forget not, Yea, in the measureless distance wheel round and again they behold thee!'

(Samuel Taylor Coleridge, from 'Hymn to the Earth', imitated from Stolberg's 'Hymne an die Erde')

Drag me, wanderer, down town quickly for Capital's light showThe Quay, wanderer ... where I trip over my own feet trying to reafforestate, Where the makers of city deny their impact via tendrils reaching out Into zones they designate as resources. Where I can locate is reduced To a place in my head I don't own, built up over millennia, an ugly Portraiture of self and lines of descent. But I continue on foot, Attempting to plough a furrow through concrete, open out to winged seed Flying in from a different timeline, ready to defy conditions and rise to the sun.

Guide me, wanderer, down town, avoiding Capital's light show For there's plenty of praise here if I can discover how to trill Without it costing you an arm and a leg, this banter around the river, Twilight sails softly billowing as relaxed as Margaret River white wine. This jigsaw puzzle of presence, giving room to manoeuvre? Were It just a few words, a snippet of text, a 'that was then, this is now' Scenario ... you know, easy come, easy go? And yet, your plates shift, And you belch and shudder under the strain of holding us up.

Drag me, wanderer, down town quickly for Capital's light showA farce, wanderer ... a glimmer of glass and skyworks, a pat on the back For 'healthy competition'. Earth, developers are not your friend - I have heard Them laughing at you as I've passed under their boardrooms, their dead nests Scanned for bugs, an exterminator ever at the ready, serving hand over foot, speculating

At their beck and call. A little sparkle has appeared in some eyes, as solarEngineers sell their vision of futures trading, glittering sulphate reflectors In the canopy, crown decline the sepia over the black \& white of ancient footage.

Guide me, wanderer, down town, avoiding Capital's light showLearning to walk through the cloud and let flow and flow through, Not like The Verve's video for Bitter Sweet Symphony - maybe Richard Ashcroft would have walked around cows or sheep or kangaroos If he'd been walking around here, chanting to himself? I have seen Echidnas trundle with such determination down the hillside, beak Set towards a veining of termites up an old York gum trunk. In childhood, I worried so much about scale looking out over things from the treehouse.

Drag me, wanderer, down town quickly for Capital's light showQuick smart, wanderer ... along the familiar beat, the worn lines in sand I can barely read, struggling for skills. I come from out where the winnowing Is glitter in the air, where pollens shake down where they can, confused As origins, looking for purchase. They struggle with political economy. An asteroid passes between the moon and the earth, coming out Of the shadows as an affront to science, to observation, to glocal (C) Denial rolled into ball-bearings. A gravel road, a secretive mine. Trucks! 
Guide me, wanderer, down town, avoiding Capital's light showAcross hot and cold reservoirs, this Carnot cycle of my unplaced body That still leaves a stain, something uncomfortable, best written-out Of records that change as needs be anyway. Roots feeding roots Surely no surprise in the co-operative take on dwelling, the walls And surveillance cameras of wealthy streets a haul from quarry holes In the blue soul of Hills rock? Each year fewer red-tailed and fewer White-tailed cockatoos, their calls streamers of naming dispersed by aerosols.

Drag me, wanderer, down town quickly for Capital's light show -

High light, wanderer ... squelching froglets' vulnerable tenacity against the cutting

Edge; terms of trade are the toxic wooden floors of metal containers and the harbour

Chock-a-block with points of purchase, reaching out; these pilgrimages

For some, not for others, distant mountains expanding to crack and fall down

End of days, night person I am, foraging among the pale tubers. No claims. Nothing.

You, wanderer, are the wanderer - I am not setting my teeth into granite, but watching.

Guide me, wanderer, down town, avoiding Capital's light show!

(John Kinsella)

\section{Villanelle In Memoriam Urs Jaeggi}

You'd have broken the form down into fragments of speech, questioned the mechanism, undone the quotes that bind the philosopher to a position, a circumstance.

I will remember for us the interplay of documents and voice in the East Berlin Literaturhaus, the notes of breaking the form down into fragments.

I will remember for us the non-alignments of syntax and image, freeing picture house endnotes that bind the philosopher to a position, a circumstance.

I will remember Deleuze and Guattari enjambments, the wolf in a shadow of the tower - unlearning rote, as we broke up the form and followed the fragments.

I will remember the depth of ink and the dénouement of a rocking horse in your Berlin flat, later of Zurich and litotes, refusing to bind the philosopher to a position, a circumstance.

For more than a quarter-century we worked by increments our 'Tractortatus' trying to respell propositions and essences - afloat on your sculptures of consequence, lines worked into fragments freeing the philosopher from a position, all circumstance.

(John Kinsella) 
John Kinsella - 9781526160072 Downloaded from manchesterhive.com at 04/26/2023 01:02:21PM via free access 